DOI: $10.17805 /$ trudy.2016.6.12

\title{
VIII МЕЖДУНАРОДНАЯ КОНФЕРЕНЦИЯ СЕРИИ «ДИСКУРС: ЗАПАД-ВОСТОК» «ХРИСТИАНСКИЕ ЦЕННОСТИ В УСЛОВИЯХ ГЛОБАЛЬНОГО ВЫЗОВА»
}

\author{
А. Н. Крылов \\ (Берлинский Вест-Ост институт, Германия)
}

Аннотация: В статье представлен обзор работы VIII Международной конференции серии «Дискурс: Запад-Восток», которая в 2016 г. прошла по теме «Христианские ценности в условиях глобального вызова». В Московском гуманитарном университете 10 октября 2016 г. прошло очередное заседание конференции.

Ключевые слова: конференция; обзор; христианские ценности; «Дискурс: Запад-Восток»; Московский гуманитарный университет

\section{“CHRISTIAN VALUES UNDER GLOBAL CHALLENGE”: 8TH INTERNATIONAL CONFERENCE IN THE “DISCOURSE: EAST/WEST" SERIES}

\author{
A. N. Krylov \\ (West-Ost Institute, Berlin, Germany)
}

\begin{abstract}
This is a summary of the 8th International conference in the "Discourse: East/West" series, which took place in Moscow University for the Humanities on October 10, 2016. This session was devoted to the issue of "Christian values under global challenge".

Keywords: conference; overview; Christian values; "Discourse: East/West"; Moscow University for the Humanities

10 октября 2016 г. в Московском гуманитарном университете состоялась VIII Международная конференция серии «Дискурс: Запад-Восток» по теме «Христианские ценности в условиях глобального вызова». Организаторами конференции выступили Московский гуманитарный университет, Национальный институт бизнеса, Институт Европы Российской Академии и Наук, Берлинский Вест-Ост институт и Агентство стратегических коммуникаций «Никколо М» (Россия).
\end{abstract}


Конференции «Дискурс: Запад-Восток» проводятся с 2002 г. один раз в два года в Германии и России и за полтора десятка лет уже завоевали научное признание и высокий авторитет в научном мире. Тематика конференций отражает социальные, межкультурные и экономические проблемы взаимодействия социальных институтов и общественности Западной, Центральной и Восточной Европы. Конференции не тиражируются и не преследуют коммерческих целей. Наравне с научным и прикладным анализом поднимаемых вопросов каждое из мероприятий представляет собой платформу для профессионального общения, дискуссий, получения актуальной и достоверной информации. На территории Московского гуманитарного университета конференции серии «Дискурс: Запад-Восток» состоялись уже три раза. Предыдущие конференции в МосГУ были посвящены темам корпоративного управления и взаимоотношения бизнеса, общества и политики.

Тема конференции 2016 г. был определена экспертной группой Берлинского Вест-Ост института. Для Европы она связана не только с большим количеством беженцев, но и с происходящими в ЕС социальными процессами. Актуальность христианских ценностей, по мнению экспертов, определяется также изменениями в области здравоохранения и генных технологий. Широкая общественность, политики и экономисты в ближайшие годы будут поставлены перед вопросом о роли христианских ценностей в дальнейшем развитии Европы.

Конференция «Христианские ценности в условиях глобального вызова» была посвящена вопросу о том, какую роль играют и должны играть христианские ценности в глобальном мире, в исконно христианских странах и в жизни каждого христианина. Конференция носила научный и неконфессиональный характер. Церковь поддержала проведение конференции, но выступает на ней не организатором, а экспертом. Ситуация в Восточной Европе представлена преимущественно Русской Православной Церковью, а в Центральной и Западной Европе - католической церковью. Конференция отвечает духу совместного заявления Патриарха Кирилла и Папы Римского Франциска о необходимости сотрудничества по защите христианских ценностей в мире. Предупреждающие слова и глубокое понимание ситуации в мире и обществе, выраженные в Заявлении стали для организаторов конференции значимым импульсом в подготовке форумов и дискуссий.

Открыл конференцию директор Берлинского Института професcop А. Н. Крылов. С приветствием от имени ректора МосГУ профессора И.М.Ильинского выступил ректор Национального института бизнеса профессор С. И. Плаксий. От имени организаторов, собравшихся приветствовал также Председатель совета директоров Агентства стратегических 
коммуникаций «Никколо М», заведующий кафедрой рекламы и связей с общественностью Российского экономического университета им. Г.В. Плеханова И. Е. Минтусов. Письменное приветствие из Ватикана участникам конференции прислал Президент Папского Совета по содействию Христианскому Единству кардинал К. Кох. «Вопрос христианских ценностей приобрёл в наше время, возрастающее по своей значимости значение, особенно в Европейской цивилизации, которая переживает на сегодняшний момент серьёзный кризис самоидентификации. Считаю очень важным, проведение конференции по этой теме и встречу в Москве ведущих специалистов из Восточной и Западной Европы», - отметил он.

Первое научное сообщение на конференции было сделано известным немецким философом Р. Шпеманном, обозначившим пути дискуссий по теме «Ценности и их роль в жизни человека и общества». Шпеманн отменил, что вопрос ценностей является вопросом философским, а не христианским. С точки зрения христианства, ценности, по мнению Р. Шпеманна, вторичны, первичной является правда и личность Иисуса Христа.

Доцент факультета философии МГУ им. М. В. Ломоносова И. И. Пороховская в докладе по теме «Интердисциплинарные подходы и проблема изучения ценностей» отметила, что отличительной особенностью изучение ценностей сегодня является акцент в сторону прикладной этики. Примером тому стало изучение различных видов внерациональных ценностных актов, которое осуществляется на стыке психологии, культурологи, религиоведения и философии. Корни самопожертвования и альтруизма пытаются найти на уровне существования биологических видов, где отдельная особь часто жертвует собой ради сохранения целого и т. д. Некоторые философы считают, что сфера аксиологических исследований на стыке философии и естественных наук важна и перспективна, ибо, сколь бы специфичным ни было человеческое ценностное бытие, оно не может не иметь онтологических оснований в самом существовании Космоса, в его структурно-функциональных и эволюционных универсалиях (об этом писали писатель Олдос Хаксли, христианский проповедник К.С.Льюис, социобиологи Е. О. Уилсон и К. Лоренц, психолог Ж. Пиаже, физик А. Эйнштейн, этнограф К. Леви-Стросс, российский биолог А. В. Марков).

Теоретическая справка о сущности и содержании христианских ценностей была дана в докладе доктора теологии, митрополита Московской католической архиепархии, архиепископа П. Пецци. «Секуляризированные общества и государства уже давно стремятся так или иначе свести христианство лишь к отдельным христианским ценностям, воспринимаемым как некое «гетто добрых чувств», полезных для мирного общежития граждан, но не более того. Христианство как таковое должно быть исключено из проектов и процессов развития общества, политических, 
экономических, и социальных перспектив», - отметил докладчик.

Ректор международной духовной семинарии Redemptoris Mater в Кельне С. Пане обозначил в своем выступлении актуальные ценностные дискуссии в современной Европе, а итальянский журналист и редактор «Радио Ватикан» М. Гальгано поделился аналитической информацией по теме «Влияние политики и СМИ на ценностные установки современного общества». Особый интерес вызвало выступление главного научного сотрудника отдела социальных и политических исследований Института Европы РАН профессора А. А. Красикова, возглавлявшего при Президенте РФ Б. Н. Ельцине Совет по взаимодействию с религиозными организациями. Он обозначил актуальные ценностные вызовы современной Европы, сформулировав критические позиции, как в адрес политики, так и в адрес церкви.

Вторую часть «Христианство и его влияние на жизнь современного общества» открыл профессор Московского государственного университета им. М. В. Ломоносова Ю. Ю. Петрунин, выступивший по теме «Христианство и ценностные конфликты в экономике». Эту же тепу продолжил профессор К. Шанк, представляющий университеты Фехта (Германия) и Ст. Галлен (Швейцария). Редактор немецкого журнала “Prediger und Katechet”, доктор теологии П. Зойль обозначил проблему христианства и ценностных конфликтов в локальных условиях. Его выступление было посвящено не социальной, а индивидуальной сфере ценностных проблем и дало импульс для последующих дискуссий в прениях. Влияние христианских ценностных традиций на законодательные и правовые акты Европы и мира было показано в выступлении доктора юриспруденции ведущего научного сотрудника Кельнского университета К. Яспера. Пригласило к научной полемике инновативное для исследователей религии выступление старшего научного сотрудника Институт Востоковедения РАН, редактора энциклопедии «Современная религиозная жизнь России» С. Филатова по теме «РПЦ и борьба за доминирующие ценности посредством исторической мифологии».

Завершило вторую часть конференции выступление заведующего кафедрой рекламы и связей с общественностью РЭУ им. Г. В. Плеханова И.Е.Минтусова по теме «Возможности и ошибки ценностных коммуникаций». Он отметил, что главным условием успешных коммуникаций является одинаковая система ценностей её участников. Разницу в системе ценностей российских и американских граждан И. Е. Минтусов показал на примере политических коммуникаций, ведущую роль в которых играют политические лидеры стран. Он обратил внимание ученых на «Всемирный обзор ценностей» (World Values Survey, WVS), которое проводится с 1981г. В рамках исследования выделяется две крупные категории ценностей: 
выживания/самовыражения и традиционные/секулярно-рациональные ценности. И. Минтусов отметил, что в данном случае Россия, с одной стороны, близка по ценностям к полюсу выживания, с другой стороны - paционалистична, как Германия, Норвегия и Дания. В своем выступлении И. Минтусов ссылался на американского лингвиста Джорджа Лакоффа и его теорию метафор и фундаментальный труд «Метаморфозы традиционного сознания» известного этнопсихолога С. Лурье.

Завершающей частью конференции стал экспертный форум, включавший основной доклад, выступления экспертов и большую пленарную дискуссию.

С основным докладом по теме «Актуальные вызовы и шансы для современного христианства» выступил профессор Московского государственного института международных отношений (университета) МИД РФ, Председатель Синодального отдела РПЦ по взаимоотношениям Церкви с обществом и СМИ В. Р. Легойда. «Если под общечеловеческими ценностями мы принимаем некий общий нравственный свод правил, которые признаются людьми разных культур и религий, то здесь, несмотря на различную аксиоматику мировых религий, нравственное поле разных религиозных позиций практически совпадает», - отметил он. «Если же понимать общечеловеческие ценности в смысле представления о человеке как о нулевой величине, лишенной религии, культуры, Родины, то с этим сложно согласиться с христианской позиции. Потому что именно в рамках такого мировоззрения и возникает тезис, с которым также согласиться довольно сложно: «Религия - частное дело»», - сказал докладчик. По словам В. Р. Легойды, основная опасность этого тезиса заключается в том, что он выдается не за альтернативную мировоззренческую позицию, а за некую объективную оценку социальной реальности, наряду с которой могут существовать «субъективные» представления христиан, мусульман и т. д. «Мы сегодня на конференциях говорим о ценностях, но важно понимать, что христианство - это не просто этическая или аксиологическая система, а жизнь во Христе. Конечно, в христианстве есть система ценностей, которая связана с этим главным, но в первую очередь христианство - жизнь во Христе».

Экспертные выступления были сделаны российским журналистом, экспертом в области религиозной политики, членом Совета при президенте Российской Федерации по развитию гражданского общества и правам человека М. Л. Шевченко и Депутатом Государственной Думы РФ Е.Г.Драпеко. В дискуссия приняли участие ученые из РЭУ им. Г. В. Плеханова, МосГУ, Национального института бизнеса и других вузов. Всего на конференцию приехало более 150 ученых, политиков и представителей общественности из России и 12 стран мира. Более половины участников 
и гостей конференции прибыли из стран дальнего зарубежья.

Завершилась конференция концертным выступлением лауреата международного конкурса Надежды Яныгиной, являющейся студенткой Московского гуманитарного университета по направлению «Вокальное искусство» в классе Заслуженной артистки России, профессора Э. В. Хохловой.

Поддержку в проведении конференции оказали отдел по делам молодёжи Московской Патриархии, РЭУ им. Г. В. Плеханова, издательство «Икар», телерадиокомпания «Domradio» и другие. O конференции рассказали многочисленные российские и европейские СМИ, в том числе три отечественных телеканала. Материалы конференции будут опубликованы в журнале «Знание. Понимание. Умение», а сама конференция послужила импульсом для подготовки большого европейского издания «Настольной книги европейских ценностей», которое осуществит Берлинское научное издательство „Berliner Wissenschafts-Verlag“. Это в полной мере отвечает представлениям организаторов. Основная научная и социальная значимость проведенной конференции, по мнению оргкомитета, состоит в привлечение внимания к тематике христианских ценностей, постановке новых научных задач, стимулирование научных и гражданских дискуссий, в обмене научной информацией между учеными и экспертами стран Западной и Восточной Европы.

Дата поступления: 15.11.2016 г.

Крылов Александр Николаевич - доктор философских наук, профессор, главный редактор научного журнала «Вест-Ост-Репорт», директор Берлинского Вест-Ост института. Адрес: ул. Циммерштрассе, 79-80, 10117 Берлин, Германия. Тел.: +49 30226873 70. Эл. адрес: krylov@westost.eu

Krylov Aleksandr Nikolayevich, Doctor of Philosophy, Professor, Editorin-Chief, West-Ost-Report journal; Director, West-Ost Institute, Berlin. Postal address: 79-80 Zimmerstrasse 10117 Berlin, Germany. Tel.: +49 3022687370. E-mail:krylov@westost.eu

\section{Для циитирования:}

Крылов А. Н. VIII международная конференция серии «Дискурс: Запад-Восток» «Христианские ценности в условиях глобального вызова» [Электронный ресурс] // Научные труды Московского гуманитарного университета. 2016, № 6. URL: http:// journals.mosgu.ru/trudy/article/view/383 (дата обращения: дд.мм.гг.). 